\title{
PENGARUH PENERAPAN STRATEGI PEMBELAJARAN PEER TEACHING PADA MATA KULIAH TERAPI OKUPASI TERHADAP HASIL BELAJAR MAHASISWA BERKEBUTUHAN KHUSUS DI PRODI. PENDIDIKAN LUAR BIASA IKIP PGRI JEMBER
}

\author{
Partiwi Ngayuningtyas Adi \\ Pendidikan Luar Biasa - IKIP PGRI Jember
}

\begin{abstract}
Abstrak
Strategi perkuliahan dengan metode konvesional menyebabkan sebagian mahasiswa berkebutuhan khusus kesulitan dalam mengikuti perkuliahan. Salah satu perkuliahan yang ditempuh oleh mahasiswa prodi pendidikan luar biasa adalah terapi okupasi untuk ABK. Mata kuliah terapi okupasi membahas tentang konsep terapi okupasi, konsep sensori integrasi, pengenalan alat okupasi, aktifitas-aktifitas terapi okupasi, pembuatan media terapi okupasi, pembuatan program terapi okupasi dan simulasi terapi okupasi. Capaian pembelajaran mata kuliah terapi okupasi untuk ABK adalah mahasiswa mampu menerapkan terapi okupasi dan sensori integrasi di sekolah. Dalam mencapai capaian pembelajaran diperlukan inovasi strategi yang kooperatif. Tujuan dari penelitian ini adalah mengetahui pengaruh penerapan strategi pembelajaran peer teaching pada mata kuliah terapi okupasi terhadap hasil belajar mahasiswa berkebutuhan khusus di Prodi Pendidikan Luar Biasa IKIP PGRI Jember. Metode yang digunakan dalam penelitian ini adalah metode eksperimen. Subyek yang digunakan dalam penelitan ini adalah 5 mahasiswa berkebutuhan khusus (mahasiswa tuna netra). Teknik pengumpulan data yang digunakan dalam penelitian ini adalah observasi, tes dan dokumentasi.Teknik pengumpulan data digunakan untuk mengetahui kemampuan mahasiswa berkebutuhan khusus dalam mengikuti perkuliahan terapi okupasi untuk ABK. Penelitian dilakukan di IKIP PGRI Jember. Mahasiswa berkebutuhan khusus mempelajari alat okupasi melalui teman sebayanya. Hasil penelitian ini menunjukan bahwa adanya pengaruh penerapan strategi pembelajaran peer teaching pada mata kuliah terapi okupasi terhadap hasil belajar mahasiswa berkebutuhan khusus di Prodi Pedidikan Luar Biasa IKIP PGRI Jember. Kesimpulan yang dapat diperoleh pada penelitian ini adalah adanya pengaruh yang signifikan penerapan strategi pembelajaran peer teaching pada mata kuliah terapi okupasi terhadap hasil belajar mahasiswa berkebutuhan khusus di Prodi Pendidikan Luar Biasa IKIP PGRI Jember.
\end{abstract}

Kata Kunci : Strategi Peer Teaching, Terapi Okupasi, Mahasiswa Berkebutuhan Khusus 
Pengaruh Penerapan Strategi Pembelajaran Peer Teaching Pada Mata Kuliah Terapi Okupasi Terhadap Hasil Belajar Mahasiswa Berkebutuhan Khusus Di Prodi. Pendidikan Luar Biasa Ikip Pgri Jember

Partiwi Ngayuningtyas Adi

\section{PENDAHULUAN}

Program studi Pendidikan Luar Biasa merupakan salah satu program studi yang ada di IKIP PGRI Jember. Program studi Pendidikan Luar Biasa banyak diminati oleh calon guru terutama calon guru untuk sekolah luar biasa. Salah satu mata kuliah yang ada pada program studi Pendidikan Luar Biasa adalah Terapi Okupasi Untuk Anak Berkebutuhan Khusus. Mahasiswa yang ada pada program studi Pendidikan Luar Biasa bukan hanya mahasiswa reguler tetapi juga terdapat mahasiswa berkebutuhan khusus. Mahasiswa berkebutuhan khusus yang mengikuti perkuliahan terapi okupasi untuk ABK adalah mahasiswa tunanetra dan mahasiswa tunarungu. Capaian pembelajaran pada mata kuliah terapi okupasi untuk ABK adalah mahasiswa mampu menerapkan terapi okupasi dan sensori integrasi di sekolah. Salah satu materi pada perkuliahan terapi okupasi adalah memperkenalkan alat-alat terapi okupasi kepada mahasiswa termasuk mahasiswa berkebutuhan khusus. Gangguan penglihatan pada mahasiswa tuna netra menyebabkan mahasiswa kesulitan dalam mengenal bentuk alat-alat okupasi. Hambatan pada mahasiswa berkebutuhan khusus menjadikan tantangan bagi penulis untuk mengajarkan materi alat-alat terapi okupasi pada mahasiswa berkebutuhan khusus.

Untuk mengatasi tantangan tersebut maka diperlukan strategi yang kooperatif dalam mengajar. Strategi kooperatif yang dapat digunakan untuk mengajar perkuliahan terapi okupasi adalah strategi peer teaching. Strategi peer teaching dapat diartikan dengan tutor sebaya, artinya belajar melalui teman satu kelasnya. Penerapan strategi peer teaching pada penelitian ini adalah mahasiswa reguler membantu menjelaskan tentang alat okupasi kepada mahasiswa berkebutuhan khusus (mahasiswa tunanetra). Mahasiswa reguler membantu mahasiswa tunanetra dengan menggunakan perabaan, dengan cara mahasiswa reguler merabakan alat okupasi kemahasiswa tunanetra dan menjelaskan tentang definisi, bentuk dan kegunaan alat okupasi. Selain mendapat penjelasan dari dosen, mahasiswa tunanetra juga dapat mempelajari tentang alat okupasi melalui teman sebaya (mahasiswa reguler).

Penerapan strategi peer teaching pada perkuliahan terapi okupasi bagi anak berkebutuhan khusus bertujuan agar mahasiswa tunanetra dapat mempelajari tentang alat okupasi melalui perabaan dan penjelasan suara yang disampaikan oleh teman sebayanya atau mahasiswa reguler. Sedangkan untuk mahasiswa reguler, melalui strategi peer teaching dapat mengulang kembali pemahaman mengenai alat okupasi. Penerapan strategi peer teaching diharapkan dapat meningkatkan pemahaman mahasiswa berkebutuhan khusus maupun mahasiswa reguler.

Selain meningkatkan hasil pembelajaran pada perkuliahan, penerapan strategi ini diharapkan dapat meningkatkan persepsi mahasiswa berkebutuhan khusus maupun mahasiswa reguler 
mengenai terapi okupasi serta meningkatkan kemampuan berkomunikasi mahasiswa reguler kepada teman sebayanya (mahasiswa berkebutuhan khusus). Pembelajaran merupakan proses yang dilakukan untuk membantu peserta didik agar dapat belajar dengan baik (Hardianto, 2012:5-6). Menurut Muchydin dan Kartika (2014:82) strategi peer teaching merupakan suatu strategi pembelajaran yang melibatkan teman sebaya.

\section{METODE PENELITIAN}

Jenis penelitian yang digunakan dalam penelitian ini adalah penelitian eksperimen. Desain penelitian yang digunakan dalam penelitian ini adalah "one group pretest posttest design". Desain penelitian ini digunakan untuk mengetahui kondisi subyek sebelum mendapat perlakuan (pretest) dan setelah subyek mendapat perlakuan (posttest). Penelitian ini dapat dilakukan perbandingan antara $\mathrm{O} 1$ (pretest) dan $\mathrm{O} 2$ (posttest) agar dapat mengetahui efektivitas perlakuan $\mathrm{X}$ Treatment. Populasi penelitian ini adalah mahasiswa semester 5 Pendidikan Luar Biasa IKIP PGRI Jember yang berjumlah 15 mahasiswa. Pengambilan sampel dilakukan dengan cara sampling karena penelitian populasi kurang dari 30 mahasiswa. Subyek yang digunakan dalam penelitian ini adalah 5 mahasiswa yaitu mahasiswa tunanetra. Variabel bebas dalam penelitian ini adalah strategi peer teaching. Sedangkan variabel terikat dalam penelitian ini adalah terapi okupasi. Definisi operasional variabel dari strategi peer teaching adalah strategi dimana mahasiswa berkebutuhan khusus belajar dan mempelajari tentang alat okupasi melalui mahasiswa regular. Sedangkan definisi operasional variabel dari terapi okupasi adalah salah satu matakuliah yang mempelajari tentang terapi okupasi beserta alat yang digunakan dalam terapi okupasi. Tahap persiapan pada instrument penelitian yaitu pembuatan RPP, RPS dan bahan ajar, perangkat pembelajaran dibuat dan dikonsultasikan dengan para ahli sebelum diterapkan kemahasiswa. Tahapan pelaksanaan penelitian antara lain pretest (mahasiswa berkebutuhan khusus diberikan pertanyaan mengenai alat okupasi, untuk mengetahui kemampuan awal mahasiswa sebelum diberikan perlakuan), treatment (mahasiswa regular membantu mahasiswa berkebutuhan khusus untuk memahami alat okupasi melalui penjelasan dan membantu merabakan alat okupasi kepada mahasiswa berkebutuhan khusus), posttest (penguji memberikan pertanyaan kepada mahasiswa berkebutuhan khusus dengan tujuan untuk mengetahui kemampuan mahasiswa berkebutuhan khusus setelah mendapatkan perlakuan. Beberapa teknik pengumpulan data yang digunakan dalam penelitian ini adalah metode observasi, metode tes dan metode dokumentasi. Metode observasi dilakukan dengan cara peneliti mengamati kegiatan perkuliahan secara langsung. Metode tes dilakukan dengan cara peneliti memberikan tes lisan kepada mahasiswa berkebutuhan khusus mengenai alat okupasi. Sedangkan metode dokumentasi 
Pengaruh Penerapan Strategi Pembelajaran Peer Teaching Pada Mata Kuliah Terapi Okupasi Terhadap Hasil Belajar Mahasiswa Berkebutuhan Khusus Di Prodi. Pendidikan Luar Biasa Ikip Pgri Jember

Partiwi Ngayuningtyas Adi

pada penelitian ini adalah mengumpulkan data-data mengenai jumlah dan daftar mahasiswa. Analisis data yang digunakan dalam penelitian ini adalah metode uji tanda yang ada dalam metode sistematika non parametric.

\section{HASIL PENELITIAN}

\section{Hasil Pre Test}

Sebelum metode peer teaching diterpakan dalam materi perkuliahan, diadakan pre test pada mahasiswa terkait materi yang akan disampaikan. Hal ini bertujuan untuk mengetahui kemampuan hasil belajar mahasiswa berkebutuhan khusus sebelum diberikan treatment (strategi pembelajaran peer teaching).

Dari pre test yang dilakukan, diperoleh data yang disajikan pada tabel di bawah ini:

Tabel 1 Data hasil pre test kemampuan hasil belajar mahasiswa berkebutuhan khusus sebelum mendapat treatment

\begin{tabular}{|c|c|c|}
\hline No & Nama Mahasiswa & $\begin{array}{c}\text { Nilai pre test kemampuan } \\
\text { hasil belajar mahasiswa }\end{array}$ \\
\hline 1 & Baihaqi & 40 \\
\hline 2 & Putri & 50 \\
\hline 3 & Feryanto & 50 \\
\hline 4 & Adam & 40 \\
\hline 5 & Julianto & 30 \\
\hline & Rata-rata & 42 \\
\hline
\end{tabular}

Berdasarkan tabel di atas, diketahui bahwa, hasil belajar masing-masing mahasiswa masih di bawah standar yang ditentukan. Rata-rata yang diperoleh juga masih di bawah standar, dengan nilai 42. Dari hasil tersebut, diperlukan treatment dengan manggunakan strategi peer teaching dalam penyampaian materi.

\section{Hasil Post Test}

Post test dilakukan untuk mengetahui kemampuan hasil belajar mahasiswa berkebutuhan khusus setelah mendapat treatment (strategi pembelajaran peer teaching). Treatment diberikan selama 3 kali pertemuan perkuliahan. Dari hasil post test yang dilakukan setelah treatmen, diperoleh data dalam tabel di bawah ini: 
Tabel 2 Data post test kemampuan hasil belajar mahasiswa berkebutuhan khusus setelah mendapat treatment

\begin{tabular}{|c|c|c|}
\hline No & Nama Mahasiswa & $\begin{array}{c}\text { Nilai pre test kemampuan hasil } \\
\text { belajar mahasiswa }\end{array}$ \\
\hline 1 & Baihaqi & 75 \\
\hline 2 & Putri & 80 \\
\hline 3 & Feryanto & 70 \\
\hline 4 & Adam & 75 \\
\hline 5 & Julianto & 75 \\
\hline & Rata-rata & 75 \\
\hline
\end{tabular}

Berdasarkan tabel di atas, diketahui bahwa, hasil belajar masing-masing mahasiswa mengalami perubahan. Hal ini juga terlihat dari rata-rata nilai yang diperoleh, dari yang awalnya nilai rata-rata adalah 42 , menjadi 75 .

\section{Rekapitulasi Hasil Pre Test dan Post Test}

Dari kedua hasil tersebut, yaitu hasil pre test dan post test maka dibuat rekapitulasi data untuk pengolahan data selanjutnya. Rekapitulasi data disajikan dalam tabel di bawah ini:

Tabel 3 Rekapitulasi hasil pre test dan post test kemampuan hasil belajar mahasiswa berkebutuhan khusus

\begin{tabular}{|c|c|c|c|}
\hline No & Nama Mahasiswa & pre test & post test \\
\hline 1 & Baihaqi & 40 & 75 \\
\hline 2 & Putri & 50 & 80 \\
\hline 3 & Feryanto & 50 & 70 \\
\hline 4 & Adam & 40 & 75 \\
\hline 5 & Julianto & 30 & 75 \\
\hline & Rata-rata & $\mathbf{4 2}$ & $\mathbf{7 5}$ \\
\hline
\end{tabular}


Pengaruh Penerapan Strategi Pembelajaran Peer Teaching Pada Mata Kuliah Terapi Okupasi Terhadap Hasil Belajar Mahasiswa Berkebutuhan Khusus Di Prodi. Pendidikan Luar Biasa Ikip Pgri Jember

Partiwi Ngayuningtyas Adi

\section{Hasil Probilitas Tanda}

Probilitas dilakukan untuk melihat pengaruh kemajuan yang diberikan antara pre test dan post test.

Tabel 4 Tabel probilitas tanda hasil pre test dan post test kemampuan hasil belajar mahasiswa berkebutuhan khusus

\begin{tabular}{|c|c|c|c|c|}
\hline No & Nama Mahasiswa & Pre test & Post test & $\begin{array}{c}\text { Perubahan } \\
(+/-)\end{array}$ \\
\hline 1 & Baihaqi & 40 & 75 & + \\
\hline 2 & Putri & 50 & 80 & + \\
\hline 3 & Feryanto & 50 & 70 & + \\
\hline 4 & Adam & 40 & 75 & + \\
\hline 5 & Julianto & 30 & 75 & $\sum=7$ \\
\hline
\end{tabular}

\section{Pembahasan}

Berdasarkan hasil analisis data menunjukkan bahwa adanya pengaruh penerapan strategi pembelajaran peer teaching pada mata kuliah terapi okupasi terhadap hasil belajar mahasiswa berkebutuhan khusus di Prodi Pendidikan Luar Biasa IKIP PGRI Jember. Hal ini dapat dilihat dari besarnya nilai $\mathrm{ZH}$ atau $\mathrm{Z}$ hitung lebih besar dibandingkan dengan nila Ztabel yang saat dilihat pada uji satu sisi sehingga dapat diputuskan Ho ditolak dan Ha diterima. Kesimpulannya adalah adanya pengaruh yang signifikan penerapan strategi pembelajaran peer teaching pada mata kuliah terapi okupasi terhadap hasil belajar mahasiswa berkebutuhan khusus di Prodi Pendidikan Luar Biasa IKIP PGRI Jember.

Hasil analisis data dipenelitian ini dapat diketahui $n=7$, dengan $\alpha=5 \%(0,05)$. Hasil pengujian menunjukkan nilai ditemukan nilai $\mathrm{Z}$ hitung $=2,616$, nilai $\mathrm{Z}$ tabel $=1,645$, karena nilai $\mathrm{Zh}$ $>\mathrm{Z}$ tabel yaitu 2,416 > 1,645 maka Ho ditolak dan H1 diterima. Kesimpulannya bahwa ada pengaruh penerapan strategi pembelajaran peer teaching pada mata kuliah terapi okupasi terhadap hasil belajar mahasiswa berkebutuhan khusus di Prodi Pendidikan Luar Biasa IKIP PGRI Jember.

Kemampuan hasil belajar mahasiswa berkebutuhan khusus mengalami peningkatan setelah diberiikan treatment dengan menerapkan strategi pembelajaran peer teaching. Hal ini dapat dilihat dari perbandingan antara hasil belajar mahasiswa berkebutuhan khusus sebelum mendapatkan treatment (pre test) dan setelah mendapatkan treatment (post test) yang menunjukkan adanya selisih yang diperoleh mahasiswa berkebutuhan khusus. Dari data yang diperoleh dapat diketahui bahwa 
hasil belajar mahasiswa berkebutuhan khusus sebelum mendapat treatment (pre test) rata-rata di bawah standart, setelah mendapatkan treatment (post test) hasil belajar mahasiswa berkebutuhan khusus mengalami peningkatan. Hal ini membuktikan bahwa penerapan strategi pembelajaran peer teaching berpengaruh terhadap hasil belajar mahasiswa berkebutuhan khusus di Prodi Pendidikan Luar Biasa IKIP PGRI Jember.

\section{SIMPULAN DAN SARAN}

\section{Simpulan}

Berdasarkan hasil data penelitian secara keseluruhan mengenai pengaruh penerapan strategi pembelajaran peer teaching pada mata kuliah terapi okupasi terhadap hasil belajar mahasiswa berkebutuhan khusus di Prodi Pendidikan Luar Biasa IKIP PGRI Jember, maka dapat disimpulkan bahwa terdapat pengaruh penerapan strategi pembelajaran peer teaching pada mata kuliah terapi okupasi terhadap hasil belajar mahasiswa berkebutuhan khusus di Prodi Pendidikan Luar Biasa IKIP PGRI Jember dan dibuktikan dari nilai pre test 42 dan nilai post test 75 serta dapat dikatakan Ho ditolak dan Ha diterima.

\section{Saran}

Saran untuk peneliti selanjutnya adalah dalam penerapan strategi peer teaching diharapkan peneliti mengkondisikan dan menyesuaikan dengan kebutuhan mahasiswa berkebutuhan khusus. Pendekatan terhadap masing-masing mahasiswa saat proses perkuliahan juga sangatlah diperlukan.

\section{DAFTAR PUSTAKA}

Muchyidin Arif, Kartika Iis. 2014. Perbandingan pemahaman Matematika Siswa Antara Kelas Yang Menggunakan Metode Student Facilitator And Explaining Dengan Metode Peer Teaching Pokok Bahasan Bangun Ruang Sisi Datar.

Hardianto. 2012. Belajar Dan Pembelajaran. Kampus Univesitas Pasir Pengaraian: UPP Press.

Sugiyono. 2016. Metode Penelitian Kuantitatif, Kualitatif, dan $R \&$ D. Bandung: Alfabeta.

Sugiyono. 2015. Statistik Nonparametris Untuk Penelitian. Bandung: Alfabeta.

Purwoko Hadi (2007). Komunikasi Aktif Bagi Tunanetra: Aktifitas Dalam Pembelajaran Pada Sistem Pendidikan Inklusif. Jakarta: Departemen Pendidikan Nasional, Direktorat Jenderal Pendidikan Tinggi, Direktorat Ketenagaan. 